$\operatorname{cocos}(1997), 12,72$ - 78

Printed in Sri Lanka

\title{
SIGNIFICANCE OF NON APPLIED ELEMENTS IN COCONUT PRODUCTIVITY
}

\author{
T.I. Mathewkutty; N.N. Potti," and E. Tajuddin"*
}

\begin{abstract}
A critical evaluation of nutritional factors involved in coconut productivity was carried out during 1991-1994. West Coast Tall palms aged 25 to 35 years varying in yield from 6 to 163 nuts per year growing in three locations viz. Regional Agricultural Research Station, Pilicode, Agricultural Research Station, Mannuthy and Coconut Research Station, Balaramapuram under regular management constituted the experimental material. The relationship of individual nutrient contents in respect of 10 elements were worked out. First order nutrient ratios in respect of these elements were also studied. The results showed that continuous use of conventional fertilizers have lead to a stage of negative response for them. It also indicated that deficiency of non recommended and non applied elements like $\mathrm{Mg}$ and $\mathrm{S}$ and excess of $\mathrm{Ca}, \mathrm{Fe}$ and $\mathrm{Mn}$ limits coconut yield. This points to importance of balanced nutrition for problem management and better productivity in coconut.
\end{abstract}

\section{INTRODUCTION}

Nutritional management is recognised as the most important generative means of yield in any crop. Growth and yield processes are dependent not on $\mathrm{N}, \mathrm{P}$ and $\mathrm{K}$ alone but on 16 or more elements designated as functional elements. More or less exclusive confinement to application of $\mathrm{N}, \mathrm{P}$ and $\mathrm{K}$ is based on the concept of their possible limiting influences on the one side and possible native sufficiency of others. Evidently this does not take into account the negative interactions among elements at secondary and micro nutrient level nor the possibłe antagoniştic effects of natural accumulation of

\footnotetext{
* Deputy Director, Coconut Development Board, Kochi -16

** Professor of Agronomy, Horticultural College, Vellanikkara

*** Director of Extension, Kerala Agricultural University Vellanikkara.
} 
specific elements due to removal or the possibility of one or the other element becoming insufficient in course of time. This is especially so in a crop like coconut which depends on the same soil volume for many decades for its nourishment and with zero recycling of its own parts. Problem management of coconut has to be viewed in this perspective. Consistently low national productivity of 33 nuts/palm/year in place of potential of over 100 nuts/palm/year necessitates a total nutritional approach for health and productivity of palms. The significance and urgency of such an approach has been brought out in this paper based on the experimental results generated from regularly well managed palms.

\section{MATERIALS AND METHODS}

The studies were conducted in the college of Horticulture Vellanikkara of the Kerala Agricultural University during 1991-94. Experimental materials consisted of 800 selected west coast tall palms, maintained in laterite soil conditions at Regional Agricultural Research Station Pilicode, Agricultural Research Station, Mannuthy and in red soil at Coconut Research Station, Balaramapuram ranging in yield from 6 to 163 nuts/palm/year, aged 30 to 40 years. The palms were grown under rainfed condition and were receiving fertilizers and other management practices according to the recommendations of the Kerala Agricultural University (Annon. 1986).

Leaf samples were collected from the 14 th frond and were analysed for macro, secondary and micro elements viz. N, P, K, Ca, Mg, S, Cl , Fe, Mn and $\mathrm{Zn}$ employing titrimetric, spectrophotometric, flame photometric or atomic absorption spectrophotometric methods depending on the element. Simple correlation of leaf elemental composition with yield was worked out to identify the first order interactions of elements in plants.

$\because \quad$ Palms were classified into high and low yielding groups and Diagnosis andd Recommendation Integrated System (DRIS) norms as per Beaufils (1973) were worked out (Mathewkutty, 1994). This was used to study the pattern of nutrient interactions and their variation in the low and high yield sub population.

\section{Results and discussion :}

Data on the correlation $(r)$ between foliar nutrient concentration and yield of coconut palms in respect of 10 elements studied in different locations/situation and pooled are presented in Table 1. 
Table 1 Correlations $(r)$ between foliar nutrien Concentrations and yield.

\begin{tabular}{|l|c|c|c|c|r|}
\hline Nutrient & Pilicode & Mannuthy & Balaramapuram & Lateriate & Pooled \\
\hline & $* *$ & & $* *$ & $* *$ & $* *$ \\
$\mathrm{~N}$ & -0.855 & 0.201 & -0.912 & -0.683 & -0.675 \\
$\mathrm{P}$ & -0.247 & 0.378 & 0.603 & 0.362 & 0.696 \\
& & $* *$ & $*$ & $* *$ & \\
$\mathrm{~K}$ & 0.154 & -0.657 & 0.487 & -0.574 & -0.400 \\
& & & $* *$ & & $* *$ \\
$\mathrm{Ca}$ & -0.022 & -0.195 & -0.824 & -0.236 & -0.576 \\
$\mathrm{Mg}$ & 0.212 & -0.202 & -0.240 & 0.001 & 0.399 \\
$\mathrm{~S}$ & $* .798$ & -0.080 & 0.316 & 0.573 & 0.719 \\
$\mathrm{Cl}$ & -0.125 & 0.174 & 0.070 & 0.068 & 0.005 \\
$\mathrm{Fe}$ & -0.435 & 0.486 & 0.505 & 0.396 & -0.213 \\
$\mathrm{Zn}$ & 0.428 & 0.432 & -0.010 & -0.197 & 0.038 \\
$\mathrm{Mn}$ & 0.275 & 0.439 & -0.644 & 0.440 & 0.217 \\
& & & & & \\
\hline
\end{tabular}

* Significant at $5 \%$ level.

* Significant at $1 \%$ level. 
It can be seen that all the elements studied in the experiment have exerted some influence on yield. Nitrogen content has expressed an almost uniformly negative significant relation with yield and potassium has a significant negative influence under Mannuthy situation and laterite soil condition. Calcium has shown a negative influence under all situations. Sulphur expressed the most significant relationship. Iron, Zinc, Manganese, and Phosphorus expressed soil specific responses to coconut productivity.

These results showed that productivity of coconut is governed by all elements and that the nature and magnitude of influence varies with soil types. This elucidate the contention that research should urgently expand to the non applied elements especially in the light of the negative influence of $\mathrm{Fe}$ and $\mathrm{Mn}$ and the positive influence of $\mathrm{S}$ and $\mathrm{Zn}$. The negative influence of $\mathrm{Fe}$ and $\mathrm{Mn}$ is highly significant in the light of the fact that nutritional management should be aimed to minimise their absorption. The results also cast doubts on the validity of regular liming based on the coneept of soil acidity as it is negatively influencing palm productivity.

Sulphur and Magnesium showed an almost positive correlation indicating that they should find a place in nutrient management in all locations. Magnesium is known necessary for chlorophyll and Sulphur for Nitrogen metabolism. Mathewkutty el al (1995) have reported that negative relations of nitrogen to productivity is not a direct nitorgen effect but a Sulphur induced effect and $\mathrm{Mg}$ effect is masked by calcium effect. This calls for rec-

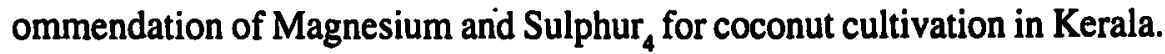

Data on the significant mean content of elements as well as the nutrient ratio and their variation in low and high yield palm populations are given in Table 2.

Comparison of the leaf composition of $\mathrm{N}, \mathrm{P}, \mathrm{Ca}$ and $\mathrm{Mg}$ revealed that $\mathrm{N}$ and $\mathrm{Ca}$ contents have to be reduced in the leaf for increasing productivity. TheTable further shows that $\mathrm{P}$ and $\mathrm{Mg}$ content in the plant tissue has to be increased for obtaining higher productivity. This in turn suggests that application of $\mathrm{Ca}$ for the purpose of neutralising acidity will have to be dispensed with.

The apparent result of reduction in $\mathrm{N}$ content with higher yields have to be viewed in the context of $\mathrm{N} / \mathrm{Mg}$ and $\mathrm{N} / \mathrm{S}$ ratios. Higher productivity calls for an increase of $\mathrm{Mg}$ and $\mathrm{S}$ in relation to $\mathrm{N}$ suggesting yield limiting influences come from a real and apparent deficiency of $\mathrm{Mg}$ and $\mathrm{S}$. This 
Table 2 - Significant elemental composition and nutrient ratios in low and high yielding palms.

\begin{tabular}{|lcccccccc|}
\hline & \multicolumn{2}{c}{ Low yield Group (A) } & \multicolumn{2}{l}{ High yield group(B) } & $\begin{array}{l}\text { Variance } \\
\text { ratio }\end{array}$ \\
$\begin{array}{l}\text { Nutrient } \\
\text { Nutrient } \\
\text { ratio }\end{array}$ & $\begin{array}{c}\text { Mean } \\
(\mathrm{SA})\end{array}$ & $\begin{array}{l}\text { Variance } \\
(\%)\end{array}$ & & $\begin{array}{l}\text { Mean } \\
\text { (SB) }\end{array}$ & $\begin{array}{l}\text { Variance } \\
(\%)\end{array}$ & CV & (SASB) \\
\hline $\mathrm{N}$ & 1.680 & 0.136 & 21.96 & 1.520 & 0.067 & 16.97 & 2.04 \\
$\mathrm{P}$ & 0.160 & 0.001 & 23.75 & 0.190 & 0.002 & 24.61 & 1.52 \\
$\mathrm{Ca}$ & 0.309 & 0.008 & 28.16 & 0.245 & 0.005 & 27.35 & 1.68 \\
$\mathrm{Mg}$ & 0.191 & 0.001 & 19.37 & 0.199 & 0.001 & 13.07 & 1.94 \\
$\mathrm{~N} / \mathrm{Mg}$ & 9.230 & 11.020 & 35.97 & 7.680 & 1.790 & 17.42 & 6.15 \\
$\mathrm{~N} / \mathrm{S}$ & 17.330 & 100.470 & 57.81 & 9.460 & 10.760 & 34.67 & 9.34 \\
$\mathrm{P} / \mathrm{S}$ & 1.440 & 0.291 & 37.43 & 1.160 & 0.148 & 33.12 & 1.97 \\
$\mathrm{P} / \mathrm{Fe}$ & 5.250 & 5.620 & 45.14 & 7.410 & 11.280 & 45.32 & 2.00 \\
$\mathrm{Ca} / \mathrm{N}$ & 0.195 & 0.006 & 40.00 & 0.168 & 0.004 & 38.31 & 1.45 \\
$\mathrm{Ca} / \mathrm{Cl}$ & 0.508 & 0.031 & 34.65 & 0.390 & 0.015 & 31.02 & 2.13 \\
$\mathrm{~S} / \mathrm{K}$ & 0.095 & 0.002 & 48.42 & 0.154 & 0.005 & 47.82 & 2.52 \\
$\mathrm{Fe} / \mathrm{S}$ & 0.313 & 0.024 & 49.20 & 0.190 & 0.012 & 57.60 & 1.97 \\
$\mathrm{Zn} / \mathrm{S}$ & 0.021 & $2.000 *$ & 61.90 & 0.013 & $0.400 *$ & 43.18 & 5.12 \\
$\mathrm{Mn} / \mathrm{S}$ & 0.194 & 0.013 & 59.28 & 0.137 & 0.006 & 55.40 & 2.30 \\
\hline
\end{tabular}

$C V$; Coefficient of variation

$*: \times 10^{-4}$ 
indicates that $\mathrm{Mg}$ and $\mathrm{S}$ have to be applied even at the expense of Nitrogen. Information on the role of Sulphur in formation of Phenolic compounds that add to disease resistance further points out to its inevitable inclusion for better plant health. Significant $S$ based ratios like $\mathrm{P} / \mathrm{S}$ and $\mathrm{S} / \mathrm{K}$ also confirm the need for higher ' $S$ ' content in the plant tissue for achieving higher productivity.

A further perusal of the data on $\mathrm{Fe} / \mathrm{S}, \mathrm{Zn} / \mathrm{S}$ and $\mathrm{Mn} / \mathrm{S}$ showed that these non applied elements through their uncontrolled absorption is limiting the productivity of coconut and that this limiting influence shall be effectively checked by Sulphur.

Balance between $\mathrm{P}$ and $\mathrm{Fe}$ (P/Fe ratio) will show the negative effect of Fe on P. Fe content of laterite soils has been reported to vary from 4-9\% as $\mathrm{Fe}_{2} \mathrm{O}_{3}$ (Hassan 1978).This means that higher requirement of $\mathrm{P}$ is to nullify the effect of Fe.The negative effect of $\mathrm{Ca}$ absorption has been brought out by $\mathrm{Ca} / \mathrm{N}$ and $\mathrm{Ca} / \mathrm{C}_{1}$ ratio. The negative relationship of $\mathrm{Ca}$ observed in the previous table appears to be the result of its negative interaction with $\mathrm{N}$ and $\mathrm{Cl}$.

\section{CONCLUSION}

Thus the results show that yield limiting influences of coconut are not the limitation in major nutrients that are regularly applied. It is the deficiency of some non applied elements like $\mathrm{Mg}$ and $\mathrm{S}$ and excesses of $\mathrm{Ca}, \mathrm{Fe}$, $\mathrm{Mn}$ etc. Therefore, further research on optimum levels of $\mathrm{Mg}$ and $\mathrm{S}$ as well as sources to mitigate the effect of negative contents of $\mathrm{Ca}, \mathrm{Fe}, \mathrm{Mn}$ etc. have to be found out. The negative relationships of major feitilizer nutrients call for research thrust in the direction of non applied elements which limit production of coconut at present.

All these point out to the system inducted imbalance that we accidently create due to exclusive application of $N, P$ and $K$. The advantage of organic farming and present diversion to organic management is the natural corollary of this imbalanced nutrition. 


\section{REFERENCES}

Anonymous 1986. Package of practices recommendations. Kerala agricuItural University, Mannuthy, Trichur.

Hassan M.A.1978 Chemical characteristics of laterite soils- Msc (Ag) thesis submitted to Kerala Agricultural University, Vellanikkara.

Beaufils. E.R. 1973. Diagnosis and Recommendation Intergrated System (DRIS). A general Scheme for experimentation and calibration based on principles developed from research in plant nutrition. Univ. Of Natal, South Africa. Soil. Sci.Bul.No.1.

Mathewkutty T.I. (1994). Applicability of Diagnosis and Recommendtion Integrated System (DRIS) in coconut palm (Cacos nucifera L.)Ph.D the sis submitted to Kerala Agricultural University, Vellanikkara.

Mathewkutty T.I., Potty. N.N. Tajuddin E., and Markose V.T. (1995) Intrigu ing influence of $\mathrm{Mg}$ and $\mathrm{S}$ in Coconut productivity-proceedings of VII th Kerala Science Congress. 